УДК 821(091):398

https://doi.org/10.18485/godisnjak.2021.16.3

Лидија Д. Делић*

Интитут за књижевност и уметност

Београд
Оригинални научни рад

Примљен: 25. 09. 2021.

Прихваћен: 05. 11. 2021.

\title{
КОГНИТИВНИ КИБОРЗИ ИЛИТИ - ЈЕ ЛИ ПИСМЕНОСТ ШТЕТНА?
}

У раду се у компаративном контексту самеравају научне студије усмерене на нека од кључних питања онтологије усмености - однос усмених цивилизација према логици и когнитивним основама писмености, природу сећања и заборава и њихову функцију у различитим типовима културе, статус и природу „истине”, однос фактографије и фикције - и приповетка Истинитост чињеница, истинитост осећања (2013) једног од најнаграђиванијих писаца научне фантастике, Теда Ћанга, у којој се у фиктивном кључу поставља питање шта би за људску врсту значило када би имала савршено сећање.

Кључне речи: сећање, писменост, усмена историја, епистемологија, когниција, историја, предање.

Наслов рада инспирисан је синтагмом „,когнитивни киборзи” из приповетке Истинитост чињениия, истинитост осећања (2013) америчког писца Теда Ћанга (Ted Chiang), једног од најнаграђиванијих писаца научне фантастике „свих времена”, ${ }^{1}$ и питањем које Александар Лома поставља у приступном предавању САНУ - ,Зашто је писменост штетна, и како премостити смрт?” (Лома 2014). Наведена синтагма Теда Ћанга и питање Александра Ломе стилски провокативно маркирају кључне феномене

*1idija.boskovic@gmail.com

1 Листа награда и номинација дата је на: http://www.isfdb.org/cgi-bin/eaw.cgi?11251 (11. 6. 2021). 
онтологије усмености - однос према логици и когнитивним основама писмености, природу сећања и заборава и њихову функцију у различитим типовима културе, статус и природу „истине”, однос фактографије и фикције - што су теме перманентно присутне у фолклористичко-антрополошким истраживањима и теме које на нов начин, у научнофантастичном модусу, покреће Тед Ћанг у поменутој причи.

Опевање историјских догађаја и фигурирање историји познатих личности у усменој епици били су јак замајац за самеравање удела реалија у усменопоетској фикцији од почетака изучавања српске усмене традиције до данас. Још је Вук указивао на полове могућих релација, пишући да, с једне стране, „у песмама не треба тражити истините историје”, а с друге, да у песмама о војевању Црногораца „има више историје него поезије” (Самарџија 2021: 122-123). ${ }^{2}$ За историјским идентитетом и елементима историјских судбина трагало се у поетским биографијама епских јунака од оних ретких које преткосовска епика памти, попут Војводе Момчила, страдалог пред затвореним капијама Перитеориона 1345. године (Делић 2006), и косовских подвижника, о којима постоји практично непрегледна литература (Петровић 2006), преко угарског племића Јаноша Секељија, епског Бановић Секуле, који је погинуо у Другом косовском боју 1448. године (Лукић 2016), изузетног деспота и ратника Змај-Огњеног Вука (1440-1485) (Пешикан Љуштановић 2002), до нешто позније активних ускочких првака (1537-1617) (Сувајџић 2003), Сењског заповедника Ивана Влатковића / Ивана Сењанина поглавито (Клеут 1987), и устаничких вођа и јунака (Љубинковић, Дрндарски 2012). ${ }^{3}$

Поред историјских догађаја везаних за поменуте личности (два Косовска боја, ратовања у оквиру Угарске монархије и Млетачке републике, устаничке борбе) свакако треба поменути збивања везана за смрт цара Уроша и предања о Вукашину цареубици, уобличена по интернационалном обрасцу „убиства у лову” (Милошевић Ђорђевић 2000), која су покренула жестоку полемику у круговима еминентних историчара друге половине XIX века и довела до раскида с романтичарском школом и

${ }^{2}$ Снежана Самарџија указује на то да „однос историјске чињенице и њене поетске транспозиције зависе од просторно-временског удаљавања варијаната и типа емотивне дистанце колектива" (Самарџија 2008: 29).

${ }^{3}$ У овом крајње сведеном луку поименце су издвојени јунаци којима су посвећене целовите монографије и само оне су наведене, јер је литература о односу историје и фолклорних наратива практично непрегледна. У датом контексту неопходно је ипак поменути дводелну студију Стјепана Бановића, у којој су сабране историјске чињенице о бројним хришћанским и муслиманским јунацима (Banović 1921, 1926). Парадоксално, у вези с најгласовитијим епским јунаком - Марком Краљевићем - тема односа историје и песме најмање се наметала. Његов поетски хабитус инклинирао је ка архаичнијем, митском уобличењу. 
конституисања критичке историографије. Панта Срећковић и Владимир Качановски држали су се, наиме, усмених наратива и заступали су тезу о Урошевој насилној смрти, док су Иларион Руварац и Љубомир Ковачевић доказивали да је цар Урош надживео Вукашина Мрњавчевића. Након „маратонске, национално обојене и балканског менталитета достојне дискусије" (Михаљчић 2001: 111) пресудила је коначно студија Српски изар Урош, краљь Вукашин и Дубровчани (1886) Константина Јиречека, где је на основу документа из Дубровачког архива показано да је цар Урош умро после погибије Мрњавчевића на Марици (уп. Сувајџић 2007: 247-279). Историјска основа конкретног предања је демистификована, ${ }^{4}$ што не значи да предање није преносило једну другу врсту „истинитости” - збирну историјску слику о династичкој смени и, све су прилике, жестоком сукобу краља Вукашина и цара Уроша, између осталог и зато што је краљ Вукашин сина Марка инаугурисао у „младог краља” за Урошева живота, узурпирајући тако круну и престо ${ }^{5}$ (Ћирковић 1968: 312-314; Михаљчић 2001: 117-122; Делић 2006: 137-184):

Баратајући нетачним фактографским подацима, предање проблематизује идеју историје као низа узрочно-последично повезаних факата и догађаја детерминисаних контекстом. У напорима да схвати и образложи најважније догађаје националне историје, грешећи у појединостима, предање погађа суштину. (Сувајџић 2005: 297)

У XX веку, нарочито у његовој другој половини, у измењеном друштвено-историјском, културном и медијском контексту, изменила се и транспозиција „велике” историје у песму, а продор „малих” историја постао је далеко интензивнији него што сведочи класичан корпус. Постфолклорне епске хронике - познате и ранијим бележењима - у условима политичког институционализовања (пропагирање југословенства, династичке идеологије, потом идеологије НОБ-а, назад и идеологије грађанских ратова на територији бивше СФРЈ), појаве средстава масовне комуникације и хиперпродукције - укључивале су сем ратних, које се уклапају у јуначки канон, и теме одвођења у логоре, страдања цивилног становништва, „обнове и изградње", авионских несрећа, атентата (на Владимира Роловића, примера ради), земљотреса, саобраћајних удеса, полицијских саслуша-

\footnotetext{
${ }^{4}$ На низу примера Стојан Новаковић је показао како „народна маса [...] води политику и историју тумачи" (Новаковић 1982: 33).

${ }^{5}$ Откриће једног натписа у Призрену 1966. године показало је „да је у време савладарства Уроша и Вукашина постојао и млади краљ” и да је то био син краља Вукашина, Марко, што значи да се Вукашин није „дрзнуо” само на краљевство већ и на светородну лозу Немањића: „оног тренутка када је његов син Марко постао млади краљ, поред живих савладара, потиснута је династија Немањића" (Михаљчић 2001: 118, 122). Овим чином Вукашин није само успоставио јачу централну власт већ је и отворено поставио питање нове династије.
} 
вања, изградњи хидроцентрала, смрти од грома, несрећних зарука итд. (Ђорђевић Белић 2016: 40-43, 180, 183). Са официјелним макронаративом коегзистирао је, међутим, и фолклор друштвених група другачијих идејно-политичких оријентација (Краљева војска у отаџбини, четници, љотићевци, потом дијаспора) (Исто: 174; Пандуревић, Кнежевић 2019), што је - макар са становишта изучавалаца - релативизовало и раслојило историјску слику, указујући на то да је свака историјска презентација конструкт прављен по „епској мери” (Н. Килибарда) или по мери „епске истине" (Б. Путилов) - односно по мери и потребама заједнице која је успоставља и путем ње конституише сопствени идентитет и сопствени систем вредности. Позивајући се на радове Јана Вансине (Jan Vansina) о усменој историји (Vansina 1965, 1985), те Питера Берка (Peter Burke) и Јана Асмана (Jan Assmann) о природи и обликовању историјског памћења (Berk 1999; Assmann 2005), Смиљана Ђорђевић Белић закључује да се епика „показује као вид усмене историје par excellence, опстајући не само као прича о прошлом, већ и као један од темељних видова обликовања колективних искустава заједнице”, те да „усмене и постфолклорне епске хронике представљају специфичне видове друштвених конструката, који неумитно залазе и у сферу политичке митологије" $(2016: 165,167)$.

Делећи са усменом епиком не само тематику и протагонисте (Петровић 2004: 40) већ и „етнокултурне функције” (Сувајџић 2005: 293), историјска предања на аналоган начин доприносе концептуализацији прошлости. Прихваћена као веродостојна и истинита казивања, она, како истиче Нада Милошевић Ђорђевић, у особеној повратној спрези активирају фолклорне приповедне матрице и истовремено инаугуришу представу о историји:

Мислим да снага предања лежи у томе што она, једном формиране, књижевне, сижејне обрасце прихватају као аутентичне, стварне културно-историјске чињенице; првобитну културно-историјску веродостојност замењују „епском”, да би је, затим, опет понудила као убедљиву историјску истину. (Милошевић Ђорђевић 2000: 131)

Могло би се, наравно, указати на завршне епске формуле типа „Ни ту био, ни право казао” (САНУ ІІІ, 27), „То је било, не знам је ли било” (Вук VI, 73 ) и сл. (уп. Детелић 1996: 168), као и на околност да предања могу преносити и говорници који не верују у исприповедано, о чему сведоче бројни коментари информатора (Bošković-Stulli 1975: 128; Rudan 2006; Mencej 2008: 325-329; Поповић 2014) - што би на први поглед релативизовало статус епике и историјских предања као фундирајућих историјских наратива усменог колектива. Међутим, тих је формула пропорционално 
мало, ${ }^{6}$ и, што је важније, епика упркос чињеници да нуди завршне формуле које доводе у питање веровање у исприповедано - не нуди алтернативну слику историје. Не постоји могућност самеравања више опција и арбитрирања. Арбитрирање се уводи тек из етске - истраживачке - перспективе, и епика се проглашава чињенично неутемељеном тек онда када постоји алтернативан след збивања.

Слично је и са усменим предањима. С обзиром на чињеницу да истраживачи на основу сопствених културних концепата и сопствених историјских знања процењују да ли је неки наратив „историја” или предање, да ли је вероватан или фантастичан, овај жанр постоји и опажа се:

[...] само уколико постоји не инстанца која верује у истинитост одређеног типа наратива, већ инстанца која тај тип наратива сматра неистинитим. Предања се као жанр конституишу у пресеку културних матрица чије представе о реалном [додајемо - и историјском] нису до краја подударне. Места мимоилажења тих културних концепција јесу тачке у којима одређена врста наратива стиче статус предања. (Делић 2019: 365)

Као и у случају епике - потребно је да постоје две верзије прошлости, да би једна од њих била предање. Другу верзију нуди официјелна историја, а ту смо већ у пољу „технологије писмености” и истраживања Ерика Хавелока (Eric Havelock) и Валтера Онга (Walter Ong). Друга верзија би, како показује Онг, морала бити или писана или би се симултано морали рецитовати делови текста како би се утврдило који преносилац традиције „греши”, односно уноси иновације, што се у принципу не дешава. ${ }^{7}$ Писмо je, како показује овај аутор, креирало наш концепт историје - окамењене, непромењиве, проверљиве и, захваљујући фиксираном тексту, бесконачно перпетуиране.

Најзад, пре него што пређемо на научнофантастичну интерпретацију писаних и усмених верзија историје и природе сећања и заборава, осврнућемо се кратко на однос реалног и имагинарног у аутобиографским

\footnotetext{
${ }^{6}$ Далеко је више оних које дају поверење причи: „Веруј, побро, истина је било!” (СМ 129), „Пјесма мала, ал истина здрава” (Вук VIII, 61), „Није ово шала ни превара, / Но истина све како је било!” (СМ 140) итд. (Детелић 1996: 167).

${ }^{7}$, ,Verbal memory skill is understandably a valued asset in oral cultures. But the way verbal memory works in oral art forms is quite different from what literates in the past commonly imagined. In a literate culture verbatim memorization is commonly done from a text, to which the memorizer returns as often as necessary to perfect and test verbatim mastery. In the past, literates have commonly assumed that oral memorization in an oral culture, normally achieved the same goal of absolutely verbatim repetition. How such repetition could be verified before sound recordings were known was unclear, since in the absence of writing the only way to test for verbatim repetition of lengthy passages would be the simultaneous recitation of the passages by two or more persons together. Successive recitations could not be checked against each other" (Ong 2002: 56).
} 
наративима, чија се веродостојност, по правилу, не доводи у питање. Анализе интервјуа показале су, међутим, да сећање није (или не мора бити) поуздано, и то не само зато што се временским удаљавањем од неког догађаја заборављају детаљи и у свести стапају различите животне ситуације и „слике” већ и зато што туђи наративи могу да генеришу „сећања” на догађаје у којима приповедачи нису учествовали, којих нису били сведоци или их се оптимално не могу сећати. Хронолошке реконструкције неретко показују да се информатори „сећају” и збивања у којима су могли учествовати само као одојчад, као и то да са уверљивошћу сведока приповедају о догађајима који су се одиграли пре њиховог рођења (уп. Velčić 1989; Петровић 2008; Делић 2019: 368-369):

Поверење у истинитост приче толико је да приповедачица Хасима Ватић из Кијевице „добро памти” догађаје који су се збили у години када је рођена. Сличан парадокс је присутан и у причању Сулејмана Куртановића о свадби краља Александра. Куртановић свом казивању придаје карактер непосредног, личног искуства, као да је сам био сведок догађаја који се збио једанаест година пре његовог рођења. (Ljuštanović, Pešikan-Ljuštanović 2015: 143)

Један од најнаграђиванијих аутора научне фантастике, Тед Ћанг, дао је извод инспирација за сваку од прича објављених у српском издању под насловом Издисај. Прича на коју се позивамо Истинитост чињенииа, истинитост осећања ослања се, по сведочењу аутора, најнепосредније на студије Валтера Онга:

Још крајем деведесетих година двадесетог века чуо сам презентацију о будућности персоналних рачунара, и говорник је указао на то да ће једног дана бити могуће сачувати трајни видео-снимак сваког тренутка у вашем животу. Била је то смела тврдња - у то време, простор на хард-диску био је превише скуп да би се тамо складиштио видео - али ја сам схватио да је он у праву: на крају, бићете у стању да све снимите. И мада нисам знао какав ће облик то попримити, био сам сигуран да ће то имати дубоки утицај на људску психу. Интелектуално смо свесни да су наша сећања мањкава, али ретко морамо с тиме да се суочимо. Шта би за нас значило када бисмо имали заиста тачно памћење?

Сваких неколико година присетио бих се тог питања и поново размислио о њему, али никада нисам остварио никакав напредак у припреми приче око њега [...] Онда сам прочитао Усменост и писменост Волтера Онга, књигу о утицају писане речи на усмене културе; док су неке од снажнијих тврдњи у тој књизи доведене у питање, она ми је ипак отворила очи. Сугерисала ми је како би се могла повући паралела између последњег пута када је технологија променила нашу когницију и следећег пута када ће то учинити. (Ćang 2020: 287-288)

„Последњи пут када је технологија променила нашу когницију” односи се на откриће писма и на утицај који је писмо имало на људску концептуализацију. Како је показао Валтер Онг, још је Платон - први који 
записује речи након Сократа, који је беседник - у Федру показао бојазан за утицај писане речи на ум и усмене културе. У разговору између бога Тота, изумитеља писма, и краља Египта Теута, који размишља о бенефитима божанских дарова, предност се даје усменој речи (,писменост ће код ученика пре проузроковати заборавност, јер ће престати да увежбавају своје памћење. Поуздајући се у слова, присећаће се споља уз помоћ трајних ликова уместо изнутра само од себе. Ниси пронашао подстицај за памћење, него за подсећање, и пружаш ученицима привид мудрости, а не истинску мудрост”) (Лома 2014: 33). ${ }^{8}$ Александар Лома на великом компаративном материјалу указује на отпор великих цивилизација, какве су биле староиндијска и келтска - писму и писмености:

Рекли смо да писмена фиксација хомерских епова приближно коинцидира са временом њиховог настанка, док се раздобље у којем су настајали поједини делови огромног ведског корпуса смешта између средине другог и средине првог миленија пре Христа, а његово систематско бележење почиње тек после хиљадите године хришћанске ере. Дотада се ведско свештено предање преносило искључиво усменим путем, са највећом могућом верношћу, без икаквих измена у језику, док се у свакодневном животу током векова језик мењао. У међувремену, од настанка до записивања Веда, сменила су се три раздобља језичке историје. (Лома 2014: 31)

Средином првог века пре Христа Гај Јулије Цезар, освајач Галије, осврће се у својим „коментарима о Галском рату” на обичаје њених становника, па, између осталог, пише:

Друиди обично не иду у рат и не плаћају порезе као остали [...] Кажу да тамо уче напамет велики број стихова, тако да понеки учећи проведу и по двадесет година. (Гали) сматрају да би то био грех записати, иако се за друге ствари у јавним и приватним пословима служе грчким писмом. Мислим да је тај обичај установљен из два разлога, да се друидско учење не би ширило међу простим светом и да њихови ученици ослањајући се на писану реч не би мање пажње посвећивали памћењу, јер се многима дешава да им уз такво помагало попусти способност праћења наставе и памћења. (Лома 2014: 32)

Тед Ћанг је осмислио (или наслутио) следећу степеницу у спољашњем меморисању - „машину за претрагу” видео записа ремем и софтвер који га подржава. Вођење „животних дневника” личним камерама било је практично неупотребљиво док се у фиктивној верзији збивања на тржишту није појавио претраживач чији алгоритми „могу да претраже

${ }^{8}$ „Most persons are surprised, and many distressed, to learn that essentially the same objections commonly urged today against computers were urged by Plato in the Phaedrus (274-7) and in the Seventh Letter against writing. Writing, Plato has Socrates say in the Phaedrus, is inhuman, pretending to establish outside the mind what in reality can be only in the mind. It is a thing, a manufactured product. The same of course is said of computers. Secondly, Plato's Socrates urges, writing destroys memory. Those who use writing will become forgetful, relying on an external resource for what they lack in internal resources. Writing weakens the mind" (Ong 202: 78). 
пласт сена док ви стигнете да кажете 'игла”, 9 „ННајпотпунији замисливи фото-албуми" постали су употребљиви захваљујући томе што се текст који власник субвокализује (говори у себи) приказује у доњем видном пољу мрежњаче, призивајући и приказујући истовремено догађаје који су са именованим појмовима повезани. Капацитети овог апарата и амбиције њихових прозвођача у основи јесу да „он замени [...] природну меморију”. Са скепсом коју је имао Платон према писмености и са страхом аграфијских култура да ће писмо уништити природну меморију и постати средство неконтролисане комуникације наратор приповетке размишља о ремему, процењујући које би могле бити његове добре, а које његове лоше стране. Прича је написана као диптих, од којих једна линија прати догађаје у животу наратора, а друга збивања у домородачком насељу које не познаје писмо, мада, с обзиром на то да је колонизовано, има контакт с њим. Обе линије, на различите начине, пропитују феномене сећања, „истине” и историчности. У првој - оној која прати живот приповедача - ремем ће у својству непобитног сведока оживети давнашњу свађу између оца и ћерке, коју је он с годинама у сећању моделовао по сопственом нахођењу, кривотврорећи и заборављајући детаље, и градећи о себи слику коју жели. Ремем му разбија илузије, подсећа га на најгору верзију „себе” и суочава га нанова с догађањима из прошлости. Размишљајући о могућностима и предностим ремема он закључује: „И мислим да сам пронашао праву корист од дигиталне меморије. Ствар није у томе да докажете да сте били у праву; ствар је у томе да признате да сте грешили.” - „Колико спознаје о себи самом могу да имам ако се ослоним само на своје памћење?" Разлажући даље, приповедач закључује „да су неке од кључних претпоставки на којима градите слику о себи заправо лажи. Проведите неко време користећи ремем и сазнаћете да је тако”. Истовремено, он не жели да се одрекне „проклето људског” у себи, не жели да механизам и поузданост овладају сећањем - „Као неко чији је идентитет саздан на органској меморији, осећам се угрожено због изгледа да субјективност буде уклоњена из нашег присећања догађаја":

Лакоћа претраге коју ремем пружа сасвим је задовољавајућа, али то само гребе по површини онога што Ветстоун сагледава као потенијал производа. [...] Али Ветстоун очекује да, кад се људи навикну на његов производ, упити замене обичан поступак присећања, тако да ремем буде интегрисан у саме процесе њиховог размишљања. Кад се то једном догоди, постаћемо когнитивни киборзи, практично неспособни да било шта заборавимо; дигитални видео сачуван на силицијуму с

${ }^{9}$ „Сада је с ремемом проналажење тачног тренутка постало лако, и животни дневници који су раније лежали готово пренебрегнути помно се претражују као поприште злочина, густо посуто доказима за употребу у кућним размирицама" (Ćang 2020: 159). 
додатним паритентним подацима преузимаће улогу коју су некада имали наши чеони режњеви. Како би изгледало када бисмо имали савршено памћење?

И ту је негде копча с историјским наративима и историјским предањима аграфијских друштава. „Форензичка потрага за истином” обележила је савремену цивилизацију и критичку историографију, али она не задовољава елементарне потребе оних цивилизација које су другачије устојене, па чак ни наше, која перманентно тражи излаз у причи. Доказа да се нешто другачије десило и да је „истина” негде другде не мањка - али да ли је то довољно за дисквалификацију приче? Је ли важнија прича или „истина”? И то је питање које поставља у више наврата приповедач другог дела Ћанговог диптиха: „Како папир може да приповеда причу?” Након „форензичке потраге” и докумената које је прибавила антрополошкиња која се пре више од четири деценије обрела у насељу приповедача („Европљанка по имену Рајс”, која је све запиткивала, „чак и жене и децу”), установљује се да кључна приповедна институција и кључни ауторитет у селу - Сабе „старешина кога су све локалне породице сматрале поглавицом” - не говори „истину” о пореклу становника, већ истину прилагођава актуелним потребама заједнице. На приговор писменог „дијака” - дечака који је од мисионара научио вештину читања и постао бележник у јавним расправама - он се суверено осврће:

Европљани често више верују папиру него људима [...] Ослањаш се на папир да ти саопшти оно што већ знаш, овде - Сабе га куцну по грудима. „Зар си толико проучавао папире да си заборавио шта значи бити Тивљанин"10 -

на шта се надовезује савремени приповедач:

Људи су саздани од прича. Наша сећања нису равнодушна акумулација сваке секунде коју смо проживели: она су наратив који смо саздали од одабраних момената [...] Чинило ми се да савршено памћење не може да буде наратив. [...] На једној страни су чињенице истине, на другој истине о пишчевим осећањима, ${ }^{11}$ и о томе где се оне поклапају не може унапред да одлучује ниједан спољњи ауторитет. Наша сећања су приватне аутобиографије. (Ćang 2020: 172-173)

${ }^{10}$ „In the Congo, 'truth' is what has been transmitted by the ancestors s having really happened. So long as a testimony corresponds with the testimony that preceded it, it it true. The Rundi have the same idea of historical truth, and as soon as something is accepted as a historical truth, they do not trouble to think whether it could have happened or not, or whether it really happened in the way the tradition describes. [...] But if the changes are inadvertently introduced into a tradition, hey in turn become 'true', for one or two generations at least" (Vansina 1965: 103).

${ }^{11}$ Овде се присећамо радова Наде Милошевић Ђорђевић о емоцији као истини: „О неким видовима изражавања осећања у нашој лирици” (1975) и „Емоција у српским баладама као лично и културно наслеђе" (2008). 
Након Вансининих капиталних студија $(1965,1985)$ и нека од новијих епистемолошких истраживања архаичних култура залажу се за статус усмених историја као метода трансмисије знања (Omogunwa, Onyibor 2019), ${ }^{12}$ док је когнитивна наратологија одавно обратила пажњу на наративну природу идентитета. Наратив није само „основни начин на који људска врста организује своје схватање времена" (Porter Abot 2009: 27), већ и начин на који успоставља слику о себи, појединачно и колективно. Ремем би био технологија која би искључила могућност селекције и индивидуалне интерпретације догађаја, ${ }^{13}$ писана историографија - стратегија апсолутног колективног сећања, без могућности адаптирања наратива актуелној прагми и без могућности постојања „митских”, фундирајућих макронаратива. Позивајући се на тврдње Жан Мари Шефера (Jean-Marie Schaeffer) да је фикција, што ће рећи сваки наратив - „ван истине и неистине" (Шефер 2001: 211), ${ }^{14}$ Јован Љуштановић и Љиљана Пешикан Љуштановић на основу сопствених теренских истраживања показују на који начин писана култура ипак утиче на усмену и на то да „несумњиво постоји и слој који врши одређени семантички притисак да се наратив разумева и као истинит (или неистинит) на начин на који то чини историографија" (Ljuštanović, Pešikan-Ljuštanović 2015: 137). Управо то је тачка у којој Тед Ћанг фиктивно разграђује актуелно поимање историје и предања. У домородачкој заједници коју описује постоје две речи за истину - „Наш језик има две речи за оно што се у вашем зове 'истина'. Ту је оно што је тачно, mimi, и оно што је прецизно, vough. У спору странке кажу оно што сматрају тачним; говоре mimi. Сведоци су, међутим, заклети да прецизно кажу шта се догодило; они говоре vough. Кад је Сабе чуо шта се догодило, могао је да закључи шта је тіті за свакога. Али није лагање ако странке не говоре vough, све док говоре mimi" (Ćang 2020: 176). Перма-

${ }^{12}$ „Oral Traditions are veritable method of transmitting and impacting knowledge across generations before formal writing came into existence. Hence, it is a portent source of histories that help people make sense of their world and are used to teach children and adults about important aspects of their culture. (Ruth, 2012)" (Omogunwa, Onyibor 2019: 32).

13 ,'Опрости и заборави' гласи изрека, и за наше идеализовано и великодушно ја, то је само и било потребно. Али за наше стварно ја однос између та два поступка није толико директан. У многим случајевима ми морамо понешто да заборавимо пре него што будемо у стању да опростимо; кад више не доживљавамо бол као нешто свеже, увреду је лакше опростити, што је опет чини мање вредном памћења и тако даље. Управо због те психолошке повратне спреге првобитно разарајуће увреде изгледају опростиво у одразу накнадног сагледавања" (Ćang 2020: 165).

${ }^{14}$ На истој линији је - мада с потпуно другачијим методолошким полазишима - Лубомир Долежел, који истиче да су фикционални светови скупови неостварених могућих стања ствари, да су доступни преко семиотичких канала и да су непотпуни (Doležel 2008: 28-36). 
нентно кривотворење стварности и када је о приватним животима и када је о историјским предањима и историји колектива реч - неминовно је. Апсолутна меморија је у новом издању антиутопијска верзија с којом нас суочава Тед Ћанг. И нуди другачији став од древних келтских и индијских друштава: за разлику од њих, која су памћењем покушавала да превладају смрт (Лома 2014), Ћанг упозорава на деструктивну природу апсолутне меморије и, може бити, на другачију цивилизацију, чије ће когнитивне основе условити околност да ће све бити снимљено и документовано. ${ }^{15}$

\section{ЛИТЕРАТУРА}

Вук VI: Српске народне пјесме. Скупио их и на свијет издао Вук Стеф. Караџић. Кюига шеста у којој су пјесме јуначке најстарије и средњијех времена, Љубомир Стојановић (прир.), Биоград: Штампарија Краљевине Србије, 1899.

Вук VIII: Српске народне пјесме. Скупио их и на свијет издао Вук Стеф. Караџић. Книга осма у којој су пјесме јуначке новијих времена о војевању за слободу и о војевању Црногораща, Биоград: Штампарија Краљевине Србије, 1900.

Делић 2006: Лидија Делић, Живот епске песме: „Женидба краља Вукашина" у кругу варијаната, Београд: Завод за уџбенике.

Делић 2019: Лидија Делић, Змија, а српска. Концептуализаиија у усменом фолклору, Вишеград: Андрићев институт.

Детелић 1996: Мирјана Детелић, Урок и невеста. Поетика епске формуле, Београд: Балканолошки институт, Крагујевац: Центар за научна истраживања Универзитета у Крагујевцу.

Ђорђевић Белић 2016: Смиљана Ђорђевић Белић, Постфолклорна епска хроника. Жанр на граници и границе жанра, Београд: Чигоја штампа.

Клеут 1987: Марија Клеут, Иван Сењанин у српскохрватским усменим песмама, Нови Сад: Матица српска.

Лома 2014: Александар Лома, Зашто је писменост штетна, и како премостити смрт? Оалед из упоредне историје религија, Глас САНУ CDXX, 29-37.

15 „У овом тренутку, свако од нас је приватна усмена историја. Ми поново исписујемо своју прошлост тако да одговара нашим потребама и подржавамо причу коју саопштавамо о себи. С нашим сећањем сви смо криви за виговско тумачење наше личне историје, при чему видимо свако некадашње ја као корак према нашем величанственом садашњем ја" (Ćang 2020: 187). 
Лукић 2016: Славица Лукић, Епска биографија Бановић Секуле у јужнословенском контексту. Докторска дисертација, Универзитет у Београду, Филолошки факултет.

Љубинковић, Дрндарски 2012: Ненад Љубинковић, Мирјана Дрндарски, Први српски устанак - од историје до „народне историје” и њене усмене митизащије, Београд: Наша прича плус, Опленац: Задужбинско друштво „Први српски устанак”.

Милошевић Ђорђевић 1975: Нада Милошевић Ђорђевић, О неким видовима изражавања осећања у нашој лирици, Прилози за књижевност, језик, историју и фолклор 42/1-4, 178-185.

Милошевић Ђорђевић 2000: Нада Милошевић Ђорђевић, Историјска предања на међи књижевности и историје (мотив убиства у лову). У: Од бајке до изреке. Обликовање и облици српске усмене прозе, Београд: Друштво за српски језик и књижевност, 129-139.

Милошевић Ђорђевић 2008: Нада Милошевић Ђорђевић, Емоција у српским баладама као лично и културно наслеђе (на примеру баладе Браћа и сестра), Grentzubersreitungen. Traditionen und Identiteten in Südosteuropa. Ferschrift für Gabriella Schubert, Wiesbaden: Harrasowitz Verlag, 398-407.

Михаљчић 2001: Раде Михаљчић, Крај Српског иарства, Београд: Српска школска књига, Knowledge.

Новаковић 1982: Стојан Новаковић, Историја и традиција. Изабрани радови, Сима Ћирковић (прир.), Београд: СКЗ.

Пандуревић, Кнежевић 2019: Јеленка Пандуревић, Саша Кнежевић, Иструли ми дуња у фиоци, Усменопоетско насљеђе и карика која недостаје. У: Данијела Петковић, Бошко Сувајџић (ур.), Савремена српска фолклористика VI, Београд: УФС, УБ „Светозар Марковић”, Лозница: Центар за културу, 97-120.

Петровић 2004: Соња Петровић, О неким проблемима историчности и структуре ликова косовске епике, Книжевност и језик, LI/1-2.

Петровић 2006: Соња Петровић, Рукописне и штампане усмене песме о Косовском боју у проиесу прожимања. Докторска дисертација, Београд: Филолошки факултет.

Петровић 2008: Соња Петровић, Прича и сећање: неки примери аутобиографског дискурса у фолклорним теренским записима из Србије, Книжевност и језик LV/3-4, 339-354.

Пешикан Љуштановић 2002: Љиљана Пешикан Љуштановић, 3мај Деспот Вук - мит, историја, песма, Нови Сад: Матица српска.

Поповић 2014: Данијела Поповић, Ал' ово није бајка него истинито: Дискурс верности у демонолошким предањима. У: Смиљана Ђорђевић 
Белић ет. ал. (ур.), Савремена српска фолклористика II, Београд: Институт за књижевност и уметност, Удружење фолклориста Србије, Универзитетска библиотека „Светозар Марковић”, 229-243.

САНУ III: Српске народне пјесме из необјављених рукописа Вука Стеф. Караиића. Кьига трећа, Владан Недић, Живомир Младеновић (прир.), Београд: САНУ, 1974.

Самарџија 2008: Снежана Самарџија, Биографије епских јунака, Београд: Друштво за српски језик и књижевност Србије.

Самарџија 2021: Снежана Самарџија, Увод у усмену књижевност, Зрењанин: Sezam Book.

СМ: Сима Милутиновић Сарајлија, Пјеванија ирногорска и хериеговачка, Добрило Аранитовић (прир.), Никшић: Унирекс, 1990.

Сувајџић 2003: Бошко Сувајџић, Епске песме о хајдуцима и ускоцима: антологија, Београд: Гутенбергова галаксија.

Сувајџић 2005: Бошко Сувајџић, Јунаци и маске: тумачења српске усмене епике, Београд: Друштво за српски језик и књижевност.

Сувајџић 2007: Бошко Сувајџић, Иларион Рувараи и народна књижевност, Београд: Институт за књижевност и уметност, Друштво за српски језик и књижевност Србије.

Ћирковић 1968: Сима Ћирковић, Коментари. У: Мавро Орбин, Кральевство Словена, Београд: СКЗ, 291-377.

Шефер 2001: Жан-Мари Шефер, Зашто фикиија? Нови Сад: Светови.

$$
* * *
$$

Assmann 2005: Jan Assmann, Kulturno pamćenje. Pisanje, sjećanje $i$ politički identitet $u$ ranim visokim kulturama, Zenica: Vrijeme.

Banović 2021: Stjepan Banović, O nekim historičkim licima naših narodnih pjesama, ZNŽOJS XXV/I, 57-104.

Banović 2026: Stjepan Banović, O nekim historičkim licima naših narodnih pjesama II, ZNŽOJS XXVI/I, 32-82.

Berk 1999: Piter Berk, Istorija kao društveno pamćenje, Reč LVI/2, 83-92.

Bošković-Stulli 1975: Maja Bošković-Stulli, Usmena književnost kao umjetnost riječi, Zagreb: Mladost.

Ćang 2020: Ted Ćang, Izdisaj, Beograd: Booka.

Doležel 2008: Lubomir Doležel, Heterokosmika. Fikcija i mogući svetovi, Beograd: Službeni glasnik.

Mencej 2008: Mirjam Mencej, Pozicija pripovedovalca v naracijah o čarovništvu. Problemi v komunikaciji med terensko raziskavo čarovništva. 
U: Ljubinko Radenković (ur.), Slovenski folklor i folkloristika na razmeđi dva milenijuma, Beograd: Balkanološki institut SANU, 323-337.

Ljuštanović, Pešikan-Ljuštanović 2015: Jovan Ljuštanović, Ljiljana Pešikan-Ljuštanović, Pričanje o životu i predanje između istorije i fikcije. U: O pričama i pričanju danas, Jelena Marković, Ljiljana Marks (ur.), Zagreb: Institut za etnologiju i folkloristiku, 135-158.

Omogunwa, Onyibor 2019: Ilemobayo John Omogunwa, Marcel I. S. Onyibor, Justification of Oral Testimony in Igbo and Yoruba Epistemology, Sapientia. Journal of Philosophy, 10, 28-41.

Ong 2002: Walter Ong, Orality and Literacy. The Technologizing of the Word, London, New York: Routlegde.

Rudan 2006: Evelina Rudan, Authentication Formulae in Demonological Legends, Narodna umjetnost XLIII/1, 89-111.

Vansina 1965: Jan Vansina, Oral Tradition. A Study in Historical Methodology, London: Routledge \& Kegan Paul Ltd.

Vansina 1985: Jan Vansina, Oral Tradition as History, Madison: University of Wisconsin Press.

Velčić 1989: Mirna Velčić, Personal Narratives as a Research Methođ in Folklore, Narodna umjetnost 26, 81-90.

Lidija D. Delić

COGNITIVE CYBORS OR - IS LITERACY HARMFUL?

Summary

In the comparative context, the paper examines scientific studies focused on some of the key issues of oral ontology - the relationship of oral civilizations to the logic and cognitive foundations of literacy, the nature of memory and forgetfulness and their function in different types of culture, status and nature of ,truth". fiction - and the short story The Truth of Fact, the Truth of Feeling (2013) by one of the most awarded science fiction writers, Ted Chiang, in which the question of what it would mean for the human species if it had a perfect memory is posed in a fictional key.

Keywords: memory, literacy, oral history, epistemology, cognition, history, tradition 